\title{
Intralesional Bleomycin Treatment for an Oral Squamous Cell Carcinoma in Indo-Pacific Bottlenose Dolphin (Tursiops aduncus)
}

\author{
Tomoko MINAKAWA $^{1) *}$, Sayaka TAKAHASHI ${ }^{1)}$, Daigo AZAKAMI ${ }^{2)}$, Misato NAKAMURA ${ }^{1)}$ and Keiichi UEDA ${ }^{1)}$ \\ 1) Okinawa Churashima Foundation, 888 Aza Ishikawa, Motobu-cho, Kunigami-gun, Okinawa 905-0206, Japan \\ 2) Laboratory of Veterinary Clinical Oncology, Cooperative Department of Veterinary Medicine Faculty of Agriculture, \\ Tokyo University of Agriculture and Technology, 3-5-8 Saiwai-cho, Fuchu, Tokyo 183-8509, Japan
}

[Received 8 January 2021; accepted 20 October 2021]

\begin{abstract}
This study describes the case of an Indo-Pacific bottlenose dolphin (Tursiops aduncus) that experienced clinical manifestations since March 2018. Biopsy samples from his oral mucous membrane were collected in November 2018, confirming the diagnosis of oral squamous cell carcinoma (OSCC). The dolphin was administered the nonsteroidal antiinflammatory drug meloxicam, however, the lesion continued to gradually deteriorate. Therefore, intralesional (ILES) bleomycin was administered. After several months, the lesion gradually improved without serious side effects. This case is the first report of ILES bleomycin treatment for OSCC in the Indo-Pacific bottlenose dolphin.

Key words: Indo-Pacific bottlenose dolphin, intralesional bleomycin, oral squamous cell carcinoma

— Jpn J Zoo Wildl Med 26(4) : 147-151, 2021
\end{abstract}

Oral squamous cell carcinoma (OSCC) is a malignant tumor commonly reported in cats and dogs. However, there are a few reports of the disease in Indo-Pacific bottlenose dolphins (Tursiops aduncus) [1] and bottlenose dolphins (Tursiops truncatus) as oral presentation in international association for aquatic animal medicine (IAAAM) [2, 3]. Surgery, chemotherapy, radiotherapy, and nonsteroidal antiinflammatory drugs are the treatment modalities.

In this case, the aquarium-maintained Indo-Pacific bottlenose dolphin is a male, over 46 years old captive at the end of November 2020, and its body weight was $186.0 \mathrm{~kg}$ in September 2020.

Since March 2018, the dolphin had developed a small, redlike inflammed lesion, which was suspected to result from a fishbone prick (Fig.1). Therefore, the dolphin received topical treatments with ointments, including triamcinolone acetonide (Bristol-Myers Squibb Company Tokyo, Japan),

* Corresponding author : Tomoko MINAKAWA

(E-mail: wrapajoy@gmail.com) hinokitiol, hydrocortisone acetate and ethyl aminobenzoate (Showa Yakuhin Kako Co., Ltd., Tokyo, Japan), beclomethasone dipropianate (Teijin Phama Limited, Tokyo, Japan), and povidone-iodine (Shionogi \& Co., Ltd., Osaka, Japan). The dolphin was also administrated antibiotics such as azithromycin hydrate (Pfizer Japan Inc., Tokyo, Japan) and tranexamic acid (Daiichi Sankyo Co., Ltd., Tokyo, Japan), which exert anti inflammatory effects. Although the clinical treatment was continued for several months, the lesion did not improve.

Four samples of the lesion with of approximately $5 \times 5$ $\mathrm{mm}$ in size were collected in November 2018 using sharp spoon forceps for otolaryngology or scalpel and fixed in $10 \%$ phosphate-buffered formalin solution. The histopathology results (North Lab, Hokkaido, Japan) identified the lesion as being OSCC (Fig. 2a, b).

From December 2018, the dolphin received systemic oral administration of meloxicam [1,4] once a week or once every five days for one month. The dolphin received seven courses with drip infusion, monoammonium glycyrrhizinate, glycine, and L-cysteine hydrochloride hydrate (Nipro, Osaka, Japan) to improve the liver function and famotidine (Astellas Phama, 
Tokyo, Japan) to prevent side effects. The dolphin initially responded to the treatment; however, the lesion demonstrated repeated aggression and remission. Lastly, the tumor was estimated to be deeper, with approximately $5.0 \times 2.5 \times 2.0$ $\mathrm{cm}$ in size (Fig.3). Therefore, ILES bleomycin was administrated next given the expected side effects are in general mild, consisting of wound formation with bone exposure that could be solved with antibiotics, mild tissue reactions, local swelling and local infection $[5,6]$.

Before the treatment, the dolphin was evaluated for complete blood count (pocH-100iV Diff, Sysmex Corporation, Hyogo, Japan), blood serum biochemical analysis (DRI-CHEM 7000V,
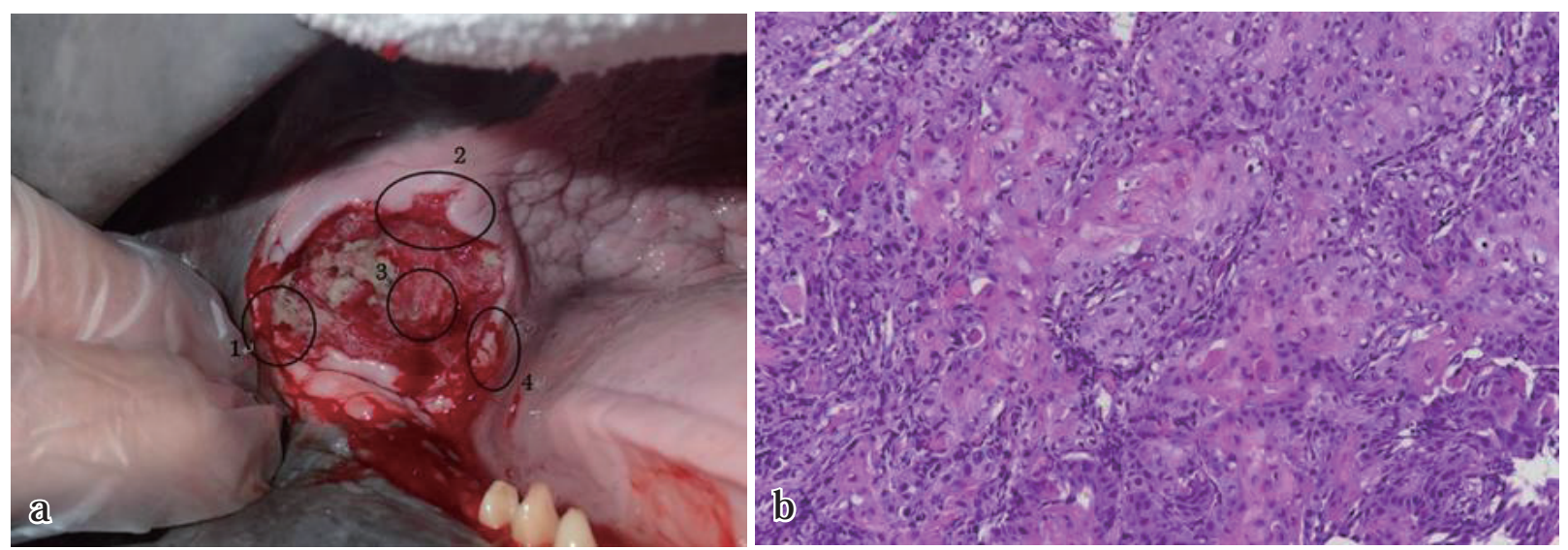

Fig. 2 The site of biopsy

a : We took four samples using sharp spoon forceps for otolaryngology or scalpel on November 18th 2018.

b : The result of pathology examination from area 2 and 4 (Fig2a). The tissue examined shows proliferation of atypical epithelial cells with irregular islands, cords, and trabeculae and invade to the adjacent tissue. The neoplastic cells have abundant eosinophilic cytoplasm and round nuclei with prominent nucleoli. And some of these cells show mild keratinization. The mitotic figures are few.

Fujifilm Corporation, Tokyo, Japan), computer tomography scan (SOMATOM Definition AS+, Siemens Healthineers, Tokyo, Japan), ultrasound (ARIETTA Prologue, Hitachi Ltd., Tokyo, Japan), and thermography (Thermo Shot, Nippon Avionics Co., Ltd., Kanagawa, Japan). All the tests showed that the dolphin was healthy, without metastasis, and with normal appetitend behavior.

Before the ILES procedure, ethyl aminobenzoate was applied (Bee Brand Medico Dental Co., Ltd., Osaka, Japan) and lidocaine hydrochloride was injected (Aspen Japan, Co., Ltd., Tokyo, Japan) inside and around the lesion under topical anesthesia. Four syringes were prepared to drew the bleomycin (Nippon

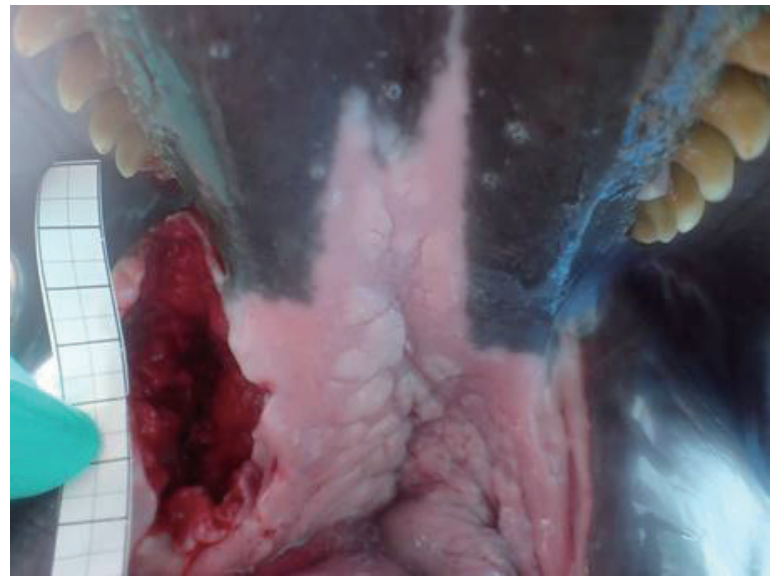

Fig. 3 The first day of the procedure on June 20th 2020. 
Table 1 Hematolory and serum chemistry of this dolphin dring intralesional bleomycin treatment ${ }^{3)}$

\begin{tabular}{|c|c|c|c|c|c|c|c|c|c|c|c|c|c|c|}
\hline & & $\begin{array}{c}\text { Range of this } \\
\text { dolphin }^{1)}\end{array}$ & $\begin{array}{c}20 / \\
06 / 23\end{array}$ & $\begin{array}{c}20 / \\
06 / 30\end{array}$ & $\begin{array}{c}20 / \\
07 / 07\end{array}$ & $\begin{array}{c}20 / \\
07 / 14\end{array}$ & $\begin{array}{c}20 / \\
07 / 21\end{array}$ & $\begin{array}{c}20 / \\
08 / 04^{2)}\end{array}$ & $\begin{array}{c}20 / \\
08 / 11^{2)}\end{array}$ & $\begin{array}{c}20 / \\
08 / 23\end{array}$ & $\begin{array}{c}20 / \\
09 / 10\end{array}$ & $\begin{array}{c}20 / \\
09 / 21\end{array}$ & $\begin{array}{c}20 / \\
10 / 05\end{array}$ & $\begin{array}{c}20 / \\
10 / 20\end{array}$ \\
\hline$\overline{W B C^{4)}}$ & (/ul) & $2,100-5,400$ & 3,800 & 4,200 & 4,100 & 3,600 & 4,500 & 7,700 & 6,100 & 3,500 & 4,800 & 2700 & 2700 & 3675 \\
\hline $\mathrm{RBC}$ & $\left(\times 10^{4} / \mu \mathrm{l}\right)$ & $292-341$ & 307.0 & 324.0 & 320.0 & 332.0 & 315.0 & 330.0 & 322.0 & 311.0 & 326.0 & 336.0 & 331.0 & 327.0 \\
\hline HGB & $(\mathrm{g} / \mathrm{dl})$ & 13.4-16.6 & 15.0 & 15.8 & 15.4 & 16.1 & 15.2 & 15.6 & 15.4 & 14.5 & 15.5 & 16.2 & 15.6 & 15.8 \\
\hline HCT & (\%) & 43-49 & 44.0 & 47.0 & 44.0 & 46.0 & 45.0 & 46.0 & 46.0 & 44.0 & 44.0 & 48.0 & 44.5 & 45.0 \\
\hline $\mathrm{Na}$ & $(\mathrm{mmol} / \mathrm{l})$ & 149-159 & 156 & 151 & 154 & 156 & 158 & 155 & 155 & 155 & 158 & 156 & 152 & 152 \\
\hline $\mathrm{K}$ & $(\mathrm{mmol} / \mathrm{l})$ & $3.2-4.5$ & 3.8 & 4.3 & 3.6 & 3.8 & 3.7 & 3.7 & 3.5 & 3.5 & 3.6 & 3.3 & 3.8 & 3.6 \\
\hline $\mathrm{Cl}$ & $(\mathrm{mmol} / \mathrm{l})$ & 115-127 & 119 & 114 & 118 & 120 & 123 & 118 & 120 & 120 & 122 & 119 & 115 & 116 \\
\hline LDH & (U/l) & 484-762 & 560 & 831 & 557 & 529 & 562 & 470 & 482 & 547 & 541 & 547 & 597 & 616 \\
\hline CPK & (U/l) & 69-162 & 98 & 83 & 95 & 95 & 103 & 67 & 79 & 89 & 110 & 90 & 103 & 116 \\
\hline GLU & $(\mathrm{mg} / \mathrm{dl})$ & $67-122$ & 98 & 94 & 104 & 91 & 102 & 106 & 100 & 89 & 103 & 112 & 93 & 93 \\
\hline ALB & $(\mathrm{g} / \mathrm{dl})$ & $3.7-4.6$ & 4.2 & 4.8 & 4.4 & 4.4 & 4.2 & 4.3 & 4.1 & 4.2 & 4.2 & 4.5 & 4.3 & 4.3 \\
\hline TCho & $(\mathrm{mg} / \mathrm{dl})$ & $117-202$ & 158 & 156 & 156 & 153 & 137 & 141 & 125 & 133 & 129 & 152 & 149 & 144 \\
\hline TG & $(\mathrm{mg} / \mathrm{dl})$ & 11-121 & 25 & 26 & 27 & 15 & 32 & 19 & 29 & 15 & 20 & 36 & 30 & 16 \\
\hline TP & (g/dl) & $11-121$ & 8.4 & 9.1 & 8.5 & 8.9 & 8.3 & 8.6 & 8.8 & 8.6 & 8.6 & 8.8 & 8.8 & 8.9 \\
\hline ALT & $(\mathrm{U} / \mathrm{l})$ & 34-91 & 44 & 53 & 43 & 53 & 53 & 50 & 51 & 61 & 55 & 65 & 70 & 85 \\
\hline AST & (U/l) & $164-252$ & 175 & 198 & 178 & 194 & 195 & 185 & 187 & 207 & 211 & 221 & 246 & 264 \\
\hline ALP & $(\mathrm{U} / \mathrm{l})$ & 295-767 & 651 & 617 & 569 & 627 & 583 & 519 & 502 & 623 & 511 & 581 & 581 & 778 \\
\hline TBil & (mg/dl) & $0.1-0.3$ & 0.1 & 1.0 & 0.1 & 0.1 & 0.1 & 0.1 & 0.1 & 0.1 & 0.1 & 0.2 & 0.2 & 0.1 \\
\hline $\mathrm{Ca}$ & $(\mathrm{mg} / \mathrm{dl})$ & 7.5-9.2 & 8.6 & 8.4 & 9.0 & 8.8 & 8.7 & 8.1 & 8.6 & 8.3 & 8.5 & 8.8 & 8.8 & 8.4 \\
\hline IP & $(\mathrm{mg} / \mathrm{dl})$ & 4.4-6.3 & 5.2 & 4.7 & 5.7 & 6.6 & 5.8 & 5.5 & 5.0 & 5.5 & 5.3 & 5.1 & 5.7 & 5.0 \\
\hline BUN & $(\mathrm{mg} / \mathrm{dl})$ & 49.9-76.7 & 54.5 & 53.2 & 53.6 & 51.1 & 56.6 & 46.6 & 50.1 & 52.8 & 55.7 & 57.7 & 52.7 & 55.1 \\
\hline CRE & $(\mathrm{mg} / \mathrm{dl})$ & $1.3-2.1$ & 1.83 & 1.70 & 1.77 & 1.84 & 1.69 & 1.60 & 1.60 & 1.68 & 1.65 & 1.61 & 1.63 & 1.44 \\
\hline $\mathrm{UA}$ & $(\mathrm{mg} / \mathrm{dl})$ & $0.1-0.8$ & 0.3 & 0.2 & 0.2 & 0.3 & 0.3 & 0.2 & 0.2 & 0.2 & 0.2 & 0.2 & 0.3 & 0.4 \\
\hline $\mathrm{NH}_{3}$ & $(\mu \mathrm{g} / \mathrm{dl})$ & $31-59$ & 35 & 50 & 50 & 44 & 32 & 62 & 42 & 57 & 29 & 42 & 31 & 39 \\
\hline GLOB & $(\mathrm{g} / \mathrm{dl})$ & 4-4.9 & 4.2 & 4.3 & 4.1 & 4.5 & 4.1 & 4.3 & 4.7 & 4.4 & 4.4 & 4.3 & 4.5 & 4.6 \\
\hline $\mathrm{Mg}$ & (mg/dl) & $1.7-2.1$ & 1.8 & 1.7 & 1.8 & 1.8 & 1.8 & 1.7 & 1.7 & 1.8 & 1.6 & 1.7 & 1.7 & 1.8 \\
\hline Fib & (mg/dL) & 201-445 & 268 & 217 & 243 & 250 & 218 & 323 & 410 & 246 & 230 & 252 & 280 & 280 \\
\hline \multicolumn{15}{|c|}{ 1) Range of this dolphin: 45samples from 2016-2020, when the dolphin was clinically healty. } \\
\hline \multicolumn{15}{|c|}{ 2) 20/08/04-20/08/11,the dolphin was received antibiotics because of bitten. } \\
\hline \multicolumn{15}{|c|}{ 3) Brief extract version taken from blood samples dring this treatment. } \\
\hline \multicolumn{15}{|c|}{$\begin{array}{l}{ }^{4)} \mathrm{WBC} \text {, white blood cell count; } \mathrm{RBC} \text {, red blood cell; HGB, hemoglobin content; HCT, hematocrit; Na, natrium; K, karium; } \mathrm{Cl} \text {, chloride; } \mathrm{LDH} \text {, lactage } \\
\text { dehydrogenase; CPK, cretinine kinase; GLU, glucose; ALB, albumin; Tcho, total cholesterol; TG, total glucose; TP, total protein; ALT, alanine } \\
\text { trasaminase; AST, aspartate aminotransferase; ALP, alkaline phosphatase; TBil, total bilirubin; Ca, calcium; IP, inorganic phosphorus; BUN, blood } \\
\text { urea nitrogen; CRE, creatinine; UA, uric acid; } \mathrm{NH}_{3} \text {, ammonia; GLOB, globlin; Mg, magnesium; Fib, fibrinogen }\end{array}$} \\
\hline
\end{tabular}

Kayaku Co., Ltd., Tokyo, Japan) into a $5 \mathrm{ml}$ lock syringe with a $25 \mathrm{G}$ needle and extension tube (200 $\mathrm{mm}$ length). Each syringe contained $2.5 \mathrm{ml}$ of bleomycin $(0.96 \mathrm{U} / \mathrm{ml})$ to avoid the use of the same needle. The maximum dose of bleomycin was of 9.6 $\mathrm{U}$ with a reference dosage of $9.6 \mathrm{U} / \mathrm{m}^{2}$, administered to dogs $[7,8]$. Bleomycin was injected inside and around the tumor without leakage [5], thus the dose of bleomycin that we used was 5.2 U-9.6 U in one procedure. After removing the needle, dry gauze was used to apply slight pressure onto the injection area to allow hemostasis. In case of hemorrhage, cotton swab moistened with 0.1\% adrenaline solution (Daiichi Sankyo) was used as compression hemostasis treatment. The duration of the procedure was approximately 10 min. Afterwards the behavior of the dolphin and occurrence of hemorrhage were monitored for one hour. The protocol was performed once a week for five weeks, and the dolphin received two courses in June 2020 and September 2020. Blood samples were collected once or twice a week to monitor the health status of the dolphin (Table 1). Based on normal range values calculated from 45 blood samples when no abnormality was found from 2016 to 2020. Hematology data of the bottlenose dolphin were also used as reference [9]. Overall, blood test results at all assessment time points, as well as the appetite and behavior were normal.

After several months on this regimen, the lesions became smaller from the edge, the granulates smoothened gradually, fewer hemorrhagic events occurred, and the mucosa expanded, especially after the second treatment administration. (Fig 4a, b). The injection site showed slight reaction and redness for a few days.

This was the first case of ILES bleomycin treatment for OSCC 


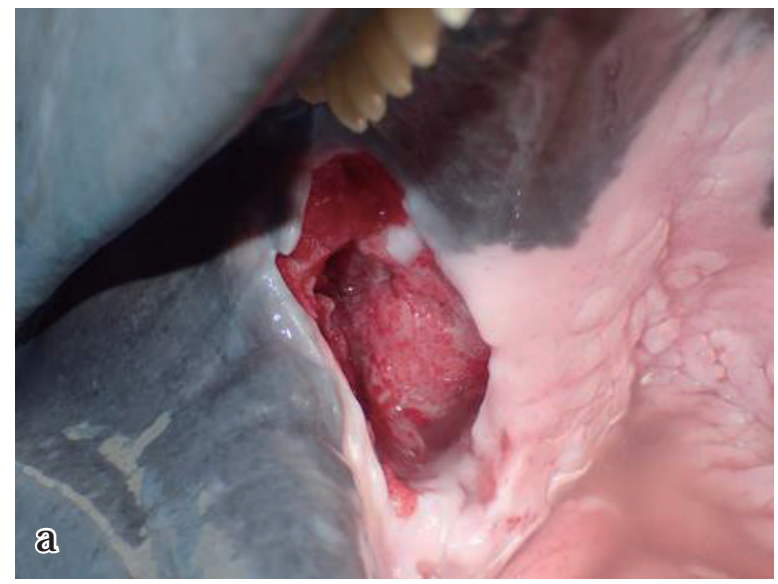

Fig. 4 November 15th 2020, improved the lesion and expanding of the dolphin's mucosa.

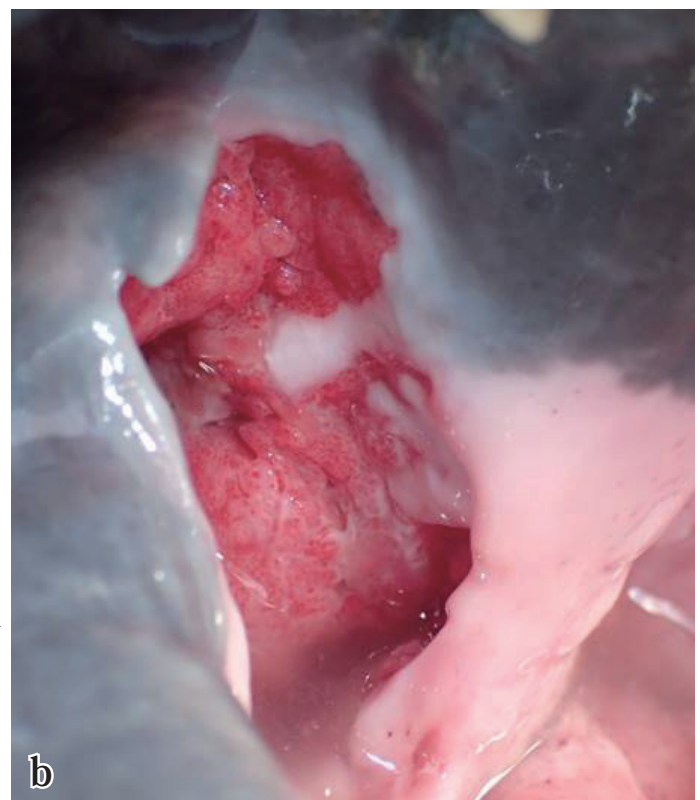

Atlanic bottlenose dolphin (Tursiops truncatus). IAAAM.

3) McKinnie CJ, Dover SR, Ogilvie G, Bossart GD. 2001. Treatment on oral squamous cell carcinoma in an Atlanta bottlenose dolphin (Tursiops truncatus). IAAAM.

4) Simeone CA, Nollens HH, Meegan JM, Schmitt TL, Jensen ED, Papich MG, Smith CR. 2014. Pharmacokinetics of singledose oral meloxicam in bottlenose dolphins (Tursiops truncatus). J Zoo Wild Med 45: 594-599.

5) Kelly JM, Belding BA, Schaefer AK. 2010. Acanthomatous ameloblastoma in dogs treatment with intralesional bleomycin. Vet Comp Oncol 8: 81-86.

6) Yoshida K, Watarai Y, Sasaki Y, Yanai, T, Masegi T, Iwasaki T. 1998. The effect of intrlesional bleomycin on canine acanthomatous eplise. J Am Anim Hosp Assoc 61: 897-902.

7) Momoi Y. 2012. Bleomycin. In Therapeutic Medication for Small Animal, 2nd ed. pp. 290. Buneido-Shuppan. Tokyo, Japan. (in Japanese)

8) Thomas K. 1911. Über die Zusammensetzung von Hund und Katze während der ersten Verdoppelungsperioden des Geburtsgewichtes. Arch Anat Physiol 1: 9-38.

9) Nollens HH, Venn-Watson S, Giki C, Mcbain JF. 2018. Cetacean medicine. In Handbook of Marine Mammal Medicine, 3rd ed. (Gulland FMD, Dierauf LA, Whitman KL. eds.), pp. 893-895, 1003-1005. CRC Press, New York. 
ロ腔扁平上皮癌に罹患したミナミバンドウイルカ（Tursiops aduncus）のブレオマイシン腫瘍内投与

\author{
皆川智子 ${ }^{1)} *$, 高橋沙矢香 ${ }^{1)}$, 啙上大吾 ${ }^{2)}$, 中村美里 ${ }^{1)}$, 植田啓一 ${ }^{1)}$ \\ 1）一般財団法人沖縄美ら島財団 ＝905-0206 沖縄県国頭郡本部町字石川888 番地 \\ 2）東京農工大学農学部共同獣医学科獣医臨床腫瘍学研究室 † 183-8509 東京都府中市幸町 3-5-8
}

[2021 年 1 月 8 日受領, 2021 年 10 月 20 日採択 $]$

要 約

2018 年 3 月より当館で飼育しているミナミバンドウイルカの口腔内粘膜に臨床症状が認められ, 同年 11 月に生検検査を行っ たところ口腔内扁平上皮癌と診断された。非ステロイド性抗炎症剤メロキシカムを投与したが, 最終的に悪化した為, ブレオマイ シンの腫瘍内投与を実施した。数か月後, 深刻な副作用なく患部は徐々に良化した。これは，ミナミバンドウイルカに対するブレ オマイシン腫瘍内投与の初症例である。

キーワード : 口腔扁平上皮癌, ブレオマイシン腫瘍内投与, ミナミバンドウイルカ

一日本野生動物医学会誌 26(4)：147-151, 2021

* 責任著者：皆川智子（E-mail: wrapajoy@gmail.com） 